\title{
PENERAPAN HASIL BELAJAR MATEMATIKA MENGGUNAKAN METODE DRILL DAN RESITASI PADA MATERI BANGUN DATAR SEGITIGA
}

\author{
Abdul Rahman Nawi ${ }^{1}$, Nurina Kurniasari Rahmawati ${ }^{2}$, Iswadi ${ }^{3}$ \\ ${ }^{1,2,3}$ Pendidikan Matematika, STKIP Kusuma Negara \\ nurinakr@stkipkusumanegara.ac.id
}

\begin{abstract}
Abstrak
Penelitian ini diharapkan dapat membuktikan perbedaan hasil belajar matematika khususnya dalam materi Bangun Datar Segitiga, antara siswa yang diajar dengan menggunakan MetodeDrill dibandingkan dengan siswa yang diajar dengan menggunakan Metode Resitasi. Penelitian ini dilaksanakan selama tigabulan tepatnya yaitu bulan April sampai dengan bulan juni 2018, dengan jumlah sampel sebanyak 60 orang siswa, tepatnya 30 orang siswa kelas VII-1 yang diberi pembelajaran dengan menggunakan metode Drill, dan 30 orang siswa kelas VII-2 yang diberi pembelajaran dengan menggunakan metode Resitasi, pemilihan sampel penelitian dilakukan secara cluster random sampling. Berdasarkan perhitungan diperoleh data bahwa ratarata hasil belajar siswa melalui metode Drill memiliki rata-rata 74,67, simpangan baku 7,16, median 72,63, serta modus 72,83 . Selanjutnya hasil belajar siswa yang diajar melalui metode Resitasi memiliki rata-rata 66,17, simpangan baku 7,15, median 65,88 serta modus 64,5. Berdasarkan uji hipotesis diperoleh nilai thitung $=4,64>$ ttabel $=2,002$. Maka diperoleh kesimpulan bahwa H1 diterima dan H0 ditolak. Kesimpulan penelitian ini adalah terdapat perbedaan yang signifikan antara hasil belajar matematika siswa yang diajar menggunakan metode Drill dengan hasil belajar matematika yang menggunakan metode Resitasi pada materi Bangun Datar Segitiga di Kelas VII SMP Fatachilah Grogol, Jakarta Barat.
\end{abstract}

Kata Kunci: Metode Drill, Metode Resitasi, Hasil Belajar.

\section{Abstract}

His research is expected to be able to prove the differences in mathematics learning outcomes, especially in the material of Flat Triangle Build-up, between students who are taught using the Drill Method compared to students who are taught using the Recitation Method. This research was conducted for three months, specifically April to June 2018, with a sample of 60 students, precisely 30 students of class VII-1 who were given learning using the Drill method, and 30 students of class VII-2 who were given learning by using the recitation method, the selection of research samples is done by cluster random sampling. Based on the calculations obtained data that the average student learning outcomes through the Drill method has an average of 74.67, standard deviation 7.16, median 72.63, and mode 72.83. Furthermore, the learning outcomes of students taught through the Recitation method had an average of 66.17 , standard deviation of 7.15 , median of 65.88 and mode 64.5 . Based on the hypothesis test obtained the value of tcount $=4.64>t_{\text {table }}$ $=2.002$. Then the conclusion is that $\mathrm{H}_{1}$ is accepted and $\mathrm{H}_{0}$ is rejected. The conclusion of this study is that there are significant differences between the mathematics learning outcomes of students taught using the Drill method and the learning outcomes of mathematics using the recitation method in the Flat Triangle Build Up material in Grade VII of Fatachilah Grogol Middle School, West Jakarta.

Keywords: Drill Method, Recitation Method, Learning Outcomes.

\section{PENDAHULUAN}

Pendidikan merupakan suatu cara pembentukan kemampuan manusia untuk menggunakan akal pikiran atau rasional mereka sebagai jawaban dalam menghadapi berbaga imasalah yang timbul di masa yang akan datang.
Salah satu tujuan pendidikanya itu untuk meningkatkan kualitas sumberday amanusia. Dengan pendidikan yang baik kita akan mudah mengikuti perkembangan zaman di masa yang akan datang sesuai dengan perkembangan situasi dan kondisi kehidupan. Tujuan dari setiap belaja rmengajara dalah untuk memperoleh hasil yang optimal. Kegiatan ini akan tercapai jika siswa sebagai objek terlibat secara aktif dari setiap belaja rmengajar adalah untuk 
memperoleh hasil yang optimal. Kegiatan ini akan tercapai jika siswa sebagai subjek terlibat secara aktif baik fisik maupun emosionalnya dalam proses belajar mengajar. Pembelajaran aktif siswa dipandang sebagai subjek bukan objek dan belajar lebih dipentingkan daripada mengajar. Di samping itu siswa ikut berpartisipasi untuk mencoba dan melakukan sendiri yang sedang dipelajari. Sedangkan dalam pembelajaran yang mengacu pada pembelajaran aktif, fungsi guru adalah menciptakan suatu kondisi belajar yang memungkinkan siswa berkembang secara optimal. Pelajaran matematika di sekolah merupakan pelajaran yang bersifat abstrak, sehingga diperlukan strategi pembelajaran yang tepat untuk mengajarkan matematika agar siswa lebih mudah memahami konsep yang terkandung dalam setiap materi yang dipelajari. Sampai saat ini masih banyak kesulitan yang dihadapi siswa dalam belaja rmatematika. Hal ini disebabkan karena banyaknya faktor, seperti anggapan bahwa pembelajaran matematika sulit dan kurang diperhatikannya keterampilan proses selama pembelajaran matematika berlangsung.

Banyak siswa menilai matematika sebagai salah satu pelajaran yang sulit dan tidak mudah dikuasai sehingga memberi kesan menakutkan. Hal ini tentunya membutuhkan daya pikir yang lebih tinggi kepada guru bagaimana menyampaikan materi matematika agar pembelajaran matematika menjadi pelajaran yang menyenangkan dan ketakutan pada mata pelajaran matematika tidak berkelanjutan. Realitas hasil pembelajaran matematika baik tingkat regional, nasional maupun lokal belum memuaskan. Demikian juga dengan hasil Ujian Nasional untuk mata pelajaran matematika dan selalu terpaku dengan angka yang rendah. Begitu pula dengan hasil observasi yang telah dilakukan di SMP Fatachilah Grogol, Jakarta Barat. Hasil UTS matematika SMP Fatachilah Grogol, Jakarta Barat tahun 2017 memiliki nilai yang rendah dan kurang memuaskan dikarenakan kurangnya motivasi dan pemahaman dengan mata pelajaran matematika, khususnya pada materi bangun datar segitiga Pada mata pelajaran ini nilai rata-rata pada materi tersebut adalah 6.70 sedangkan KKM yang ditentukan sekolah adalah 73.00 dan Berdasarkan hasil observasi yang peneliti lakukan di sekolah SMP Fatahillah Grogol, Jakarta Barat. yang dilakukan oleh para guru lebih dominan menggunakan metode ekspositori dalam menyampaikan materi tanpa di kolaborasikan dengan metode pembelajaran yang lain sehingga kegiatan pembelajaran terlihat sangat menonton karena siswa hanya di posisikan sebagai objek dan otoritas tertinggi ada pada guru. Ini menyebabkan pembelajaran kurang menarik minat para siswa dan mengakibatkan siswa kurang aktif dan kreatif dalam menggunakan kemampuan berpikirnya.

Dalam penelitian ini dipilih metode pembelajaran Drill (metode latihan siap) dan Metode Resitasi (metode pemberian tugas). Metode Drill merupakan suatu cara mengajar yang baik untuk menanamkan kebiasaankebiasaan tertentu. Latihan adalah suatu terknik mengajar yang mendorong siswa untuk melaksanakan kegiatan latihan agar memiliki ketangkasan atau keterampilan yang lebih tinggi dari apa yang dipelajari. Hal ini berarti bahwa metode drill (latihan siap) berhubungan dengan pembentukan kemahiran motoris (fisik) ataukah kemahiran yang bersifat penyesuaian seperti kemahiran untuk memecahkan suatu masalah atau kecakapan dalam penyelesaian diri terhadap suatu situasi. Agar dapat mencapai tujuan yang diharapkan guru harus memperhatikan dari pihak siswa, yaitu mereka memiliki dorongan minat dan perhatian terhadap apa yang sedang dipelajari. Pelaksanaan metode latihan siap harus tetap diusahakan untuk mengembangkan minat dan meningkatkan kemampuan siswa (Zaenal Aqib dan Ali Murtadlo: 2014). Metode Drill merupakan suatu cara mengajar dengan memberikan latihan-latihan terhadap apa yang telah dipelajari guru sehingga memperoleh suatu keterampilan tertentu. Kata latihan mengandung arti bahwa sesuatu itu selalu diulang-ulang, akan tetapi bagaimanapun juga antara situasi belajar yang pertama dan situasi belajar yang realistis, ia akan berusaha melatih keterampilannya. Apabila situasi belajar itu diubah-ubah kondisinya sehingga menuntut respon yang berubah maka keterampilan akan lebih disempurnakan.

Sedangkan Metode Resitasi (metode pemberian tugas). Metode resitasi menurut mansyur adalah metode pembelajaran yang diterapkan oleh guru, dimana guru memberikan tugas tertentu agar siswa melakukan kegiatan belajar, kemudian harus mempertangung jawabkannya. Sementara itu Soekartawi mendefinisikan bahwa metode resitasi adalah suatu cara yang menyajikan bahwa pelajaran dengan memberikan tugas kepada siswa untuk dipelajari, kemudian dipertangung jawabkan didepan kelas, disamping itu metode resitasi sering disebut dengan metode pemberian tugas, yakni metode dimana siswa diberi tugas khusus diluar jam pelajaran (Zaenal Aqib dan Ali Murtadlo: 2014). Metode pembelajaran Resitasi adalah salah satu cara yang manyajikan bahan pelajaran dengan memberikan tugas kepada siswa untuk dipelajari, kemudian di pertanggung jawabkan di depan kelas. Disamping itu, metode resitasi ini sering disebut dengan metode pemberian tugas, yakni metode dimana siswa diberi tugas khusus diluar jam pelajaran (Zaenal Aqib dan Ali Murtadlo: 2014).

Dengan demikian, pemilihan metode pembelajaran pada pembelajaran matematika sangat cocok sebagai topik tertentu, akan membantu proses belajar mengajar matematika berjalan efektif dan efisien serta memberikan pengaruh positif bagi hasil belajar matematika siswa. Berdasarkan uraian tersebut maka diduga terdapat 
Perbedaan Hasil Belajar Matematika siswayang diajarkan menggunakan Metode pembelajaran Drill (latihan siap) dan Metode Pembelajaran Resitasi (pemberian tugas) pada Materi Ajar Bangun Datar SegitigaKelas VII SMP Fatachilah Grogol, Jakarta Barat.

\section{METODE}

Sasaran Penelitian ini dilaksanakan pada siswa SMP Fatachilah Grogol, Jakarta Barat. Semester Genap Tahun Ajaran 2017-2018 pada awal bulan april sampai akhir bulan Juni 2018, penelitian ini jenis penelitian eksperimen mengungkapkan hubungan antara dua variabel. Dalam penelitian ini jenis eksperimen yang digunakan adalah eksperimen semu (quasi eksperimental). Variabel penelitian pada dasarnya adalah segala sesuatu yang berbentuk apa saja yang ditetapkan oleh peneliti untuk dipelajari sehingga diperoleh informasi tentang hal tersebut, kemudian ditarik kesimpulannya (Sugiyono: 2013). Pada penelitian ini variabel terdiri dari variabel terikat yaitu hasil belajar dan variabel bebas yaitu metode Drill dan Metode Resitasi. Metode yang digunakan dalam penelitian ini berdasarkan bidang penelitian adalah metode eksperimen. Pada penelitian ini diberikan perlakuan yang berbeda, yaitu pada kelas eksperimen I menggunakan metode Drill dan pada kelas eksperimen II menggunakan metode Resitasi. Data hasil penelitian diperoleh menggunakan tes tertulis dengan instrument soal tes guna mengukur hasil belajar siswa.

Populasi adalah wilayah generalisasi yang terdiri dari subjek yang mempunyai kualitas dan karakteristik tertentu yang ditetapkan oleh peneliti untuk dipelajari dan kemudian ditarik kesimpulannya (Sugiyono: 2015). Dalam penelitian ini populasinya adalah seluruh siswa SMP Fatachilah Grogol, Jakarta Barat, pada tahun 2016/2017 sebayak 350 siswa. Pada penelitian sampelna adalah kelas VIII-1 dengan jumlah 30 siswa sebagai kelas eksperimen I dan kelas VII-2 dengan jumlah 30 siswa sebagai kelas eksperimen 2. Teknik pengambilan sampel menggunakan Cluster Random Samping. Instrumen yang digunakan dalam penelitian ini adalah tes obyektif pilihan ganda dengan empat alternatif jawaban. Jumlah seluruh soal 30 butir soal. Untuk setiap responden yang menjawab benar satu butir soal diberi skor 1 (satu) dan yang menjawab salah diberi skor 0 (nol), dengan demikian skor terendah siswa adalah 0 dan skor tertinggi siswa adalah 30. Pengujian instrumen sangat diperlukan untuk mengetahui apakah tes tersebut sudah memenuhi persyaratan tes seperti validitas (tingkat kesahihan), reliabilitas (tingkat keajegan), dalam hal ini peneliti lakukan uji coba instrumen pada siswa kelas VII-3.

Sebelum melakukan penelitian, peneliti terlebih dahulu melakukan uji keseimbangan antara ke dua sampel, kemudian jika data seimbang atau kemampuannya sama maka dilanjutkan uji t atau uji perbedaan. Uji ini dilakukan setela uji prasyarat terpenuhi yaitu uji normalitas menggunakan uji lilifors dan Uji Homogenitas menggunakan uji Fisher.

\section{HASIL DAN PEMBAHASAN}

Uji coba soal tes hasil belajar matematika pada penelitian ini dilakukan di kelas VII-3 SMP Fatachilah Grogol, Jakarta Barat dengan jumlah responden 30 orang siswa,. Materi dalam tes ini uji coba adalah Bangun Datar Segitiga dengan jumlah soal 30 butir berbentuk pilihan ganda dengan 4 alternatif pilihan jawaban yaitu a, b, c, dan d. Berdasarkan hasil perhitungan uji validitas menggunakan poin biserial diperoleh koefisien poin biserial untuk tiap butir soal, melebihi $r$ tabel yaitu untuk signifikasi $=0.5$ dan $\mathrm{N}=30$ adalah 0.36 , sehingga dari perhitungan tersebut diperoleh soal yang valid adalah 25 butir soal.

Dari data hasil penelitian yang dideskripsikan adalah data hasil belajar matematika yang diperoleh siswa setelah tes dilaksanakan pada kelas eksperimen I dan eksperimen II. Pada eksperimen I jumlah siswa sebanyak 30 dan eksperimen II jumlah siswa 30. Setelah dilaksanakan tes maka diperoleh data hasil belajar siswa pada kelas eksperimen I dan eksperimen II sebagaimana disajikan pada Tabel 1.

Tabel 1. Statistik Hasil Tes Kelompok Sampel

\begin{tabular}{lrrrr}
\hline Kelas & $\mathrm{N}$ & $\bar{x}$ & $\mathrm{~S}$ & $S^{2}$ \\
\hline Drill & 30 & 74.67 & 51.26 & 7.16 \\
\hline Resitasi & 30 & 66.17 & 51.18 & 7.15 \\
\hline
\end{tabular}

Berdasarkan data yang ditampulkan pada tabel 1 terlihat nilai rata-rata hail belajar matematika dikelas yang menggunakan metode Drill lebih tinggi dari nilai rata-rata kelas yang dikenai metode Resitasi, untuk mengambil kesimpulan dari penelitian ini maka dilakukan uji t. Sebelum melaksanakan uji t akan dilakukan terlebih dahulu yaitu uji prasyarat data yaitu normalitas dan homogenitas. Uji normalitas data menggunakan uji lillifors dengan taraf signifikansi $\alpha=0.05$. Uji normalitas dilakukan satu kali antara kelas yang menggunakan Drill dan Resitasi. Rangkuman hasil uji normalitas data yang diperoleh disajikan pada Tabel 2.

Tabel 2. Tabel Uji Normalitas

\begin{tabular}{|c|c|c|c|c|c|}
\hline Kelas & $\mathrm{N}$ & $\mathrm{A}$ & $\mathrm{L}_{\text {hit }}$ & $\mathrm{L}_{\text {tab }}$ & Kesimpulan \\
\hline Drill & 30 & 0,05 & 0,1517 & 0,161 & Normal \\
\hline
\end{tabular}




\begin{tabular}{|c|c|c|c|c|c|}
\hline Kelas & $\mathrm{N}$ & $\mathrm{A}$ & $\mathrm{L}_{\text {hit }}$ & $\mathrm{L}_{\text {tab }}$ & Kesimpulan \\
\hline Resitasi & 30 & 0,05 & 0,1588 & 0,161 & Normal \\
\hline
\end{tabular}

Tabel 4 tampak bahwa pada taraf signifikansi $\alpha=0.05$ semua $L_{\text {hit }}$ bukan anggota daerah kritis sehingga memberikan keputusan uji $\mathrm{H}_{0}$ diterima. Berdasakan keputusan uji tersebut dapat disimpulkan bahwa kedua kelompok yaitu kelompok yang mneggunakan metode Drill dan kelompok yang menggunakan metode Resitasi berasal dari populasi yang berdistribusi normal.

Uji homogenitas variansi pupulasi dilakukan untuk mengetahui apakah populasi-populasi yang dibandingkan mempunyai variansi yang sama atau tidak. Oleh karena itu, uji homogenitas variansi populasi dilakukan sebanyak satu kali, yaitu dengan membandingkan variansi pada kelompok eksperimen I dan Eksperimen II terhadap data tes hasil belajar matematika siswa. Pengujian menggunakan uji Fisher dengan taraf signifikansi $\alpha=$ 0.05. Rangkuman hasil uji homogenitas dapat dilihat pada tabel 3 .

Tabel 3. Tabel Uji Homogenitas

\begin{tabular}{|c|c|c|c|}
\hline $\mathrm{N}$ & $\mathrm{F}_{\text {hitung }}$ & $\mathrm{F}_{\text {tabel }}$ & Kesimpulan \\
\hline 30 & 1,03 & 1,85 & $\begin{array}{c}\text { Homogen } \\
\left(\mathrm{H}_{0} \text { diterima }\right)\end{array}$ \\
\hline
\end{tabular}

Karena $\mathrm{H}_{0}$ diterima, sehingga dapat disimpulkan kedua populasi mempunyai variansi yang sama atau dengan kata lain kelas eksperimen I dan kelas eksperimen II mempunyai variansi yang homogen.

Hipotesis penelitian yang telah durumuskan menyatakan bahwa terdapat perbedaan hasil belajar matematika siswa yang menggunakan metode pembelajaran latihan siap (Drill) dengan pemberian tugas (Resitasi) pada materi bangun datar segitiga di kelas VII SMP Fatachilah Grogol, Jakarta Barat. Hipotesis yang diajukan diuji dengan menggunakan uji-t. Dari hasil penelitian diperoleht hitung $=4,64$ sedangkan perhitungant tabel dengan $\mathrm{n}=30, \mathrm{dk}=30$ $+30-2=58$ adalah 2,0021 ternyata $t_{\text {hitung }}>t_{\text {tabel }}(4,64$ $>2,0021)$ berdasarkan hasil analisis tersebut, maka dapat diambil kesimpulan diduga bahwa terdapat perbedaan antara siswa yang menggunakan metode pembelajaran latihan siap (Drill) dan siswa yang menggunakan metode pembelajaran pemberian tugas (Resitasi) pada materi bangun datar segitiga di kelas VII SMP Fatachilah Grogol, Jakarta Barat. Hasil tersebut didukung oleh beberapa peneliti antara lain (
(S. Nurhidayati., 2016) pelaksanaan metode Drill dan resitasi yang memberikan kesempatan kepada siswa untuk memberikan kebebasan siswa dalam mengemukakan ide/bertanya sehingga dapat meningkatkan keaktifan belajar siswa. Selain itu, memberikan implikasi bahwa dalam kegiatan belajar mengajar terjadi interaksi antara guru dengan siswa, interaksi tersebut diukur melalui pemberian soal-soal latihan yang dilaksanakan diakhir pertemuan sesudah guru selesai menyampaikan materi ajar. (RP Mega Eriska., 2013)Peneliti lain juga menyatakan Kemampuan pemecahan masalah siswa yang dikenai pembelajaran matematika menggunakan metode drill berbantuan "Smart Mathematics Module" pada materi barisan dan deret mencapai ketuntasan belajar yang telah ditetapkan sekolah pada kemampuan pemecahan masalah.

\section{PENUTUP}

\section{Simpulan}

Berdasarkan dari hasil penelitian dan pembahasan dapat disimpulkan bahwa hasil belajar siswa yang menggunakan model Drill memiliki perbedaan hasil belajar dengan siswa yang menggunakan metode Resitasi.

\section{Saran}

Berdasarkan hasil penelitian didapat beberapa hal yang harus diperhatikan dan menjadi pembelajaran untuk menjadi bahan masukan dalam upaya meningkatkan prestasi siswa maka penulis memberikan beberapa saran sebabagai berikut. 1). Sebaiknya dalam melaksanakan kegiatan pembelajaran di kelas menggunakan metode atau model belajara yang tepat supaya siswa mudah memahami materi pelajaran. 2). Guru selalu mendorong keterlibatan siswa lebih aktif dalam proses belajar mengajar yang akan meningkatkan hasil belajar bagi siswa.

\section{DAFTAR PUSTAKA}

Budiyono. 2016. Statistika Untuk Penelitian,. Surakarta : UNS Press.

Kusuma, A. P., \& Khoirunnisa, A. (2018). Penerapan Model Pembelajaran Kooperatif Tipe Make a Match dan Team Games Tournament terhadap Hasil Belajar. NUMERICAL: Jurnal Matematika dan Pendidikan Matematika, 1-14.

Mangentang, D. F., Kusuma, A. P., Arihati, D. B., \& Rahmawati, N. K. (2018, September). Penerapan Model Pembelajaran Brain Based Learning Dan Model Pembelajaran Accelerated Learning Cycle Terhadap 
Hasil Belajar Matematika Pada Materi Logaritma. In Seminar Nasional dan Diskusi Panel Multidisiplin Hasil Penelitian dan Pengabdian Kepada Masyarakat 2018 (Vol. 1, No. 1).

Muhammad Ali Murtadlo, Manajemen Pembelajaran Inovatif. Surabaya : Iranti Mitra Utama, 2011.

Rahmawati, N. K., \& Hanipah, I. R. (2018). Penerapan Model Pembelajaran Kooperatif Tipe Think Pair Share (TPS) Dan Model Pembelajaran Kooperatif Tipe Student Team Achievement Division (STAD) Terhadap Hasil Belajar Matematika Siswa Pada Materi Garis Singgung Lingkaran. NUMERICAL: Jurnal Matematika dan Pendidikan Matematika, 99-114.

RP Mega Eriska. 2014. Efektivitas Metode Drill Berbantuan "Smart Mathematics Module" Terhadap Kemampuan Pemecahan Masalah Siswa Kelas XI. Semarang: Skripsi UNNES.

Suharsimi Arikunto. 2013. Dasar-Dasar Evaluasi Pendidikan Edisi. 2, Jakarta: Bumi Aksara.

Sugiyono. 2015. Metode Penelitian Pendidikan Kuantitatif, Kualitatif, dan RAD, Bandung : Alfabeta.

S. Nurhidayati. 2016. Implementasi Improving Learning dengan metode Drill Dan Resitasi untuk meningkatkan keaktifan Dan prestasi belajar siswa. Surakarta: Skripsi UNS.

Zainal Aqib dan Ali Murtadlo. 2013. Kumpulan Metode Pembelajaran Kreatif \& Inovatif. Jakarta : Satu Nusa. 
Abdul Rahman Nawi ${ }^{1}$, Nurina Kurniasari Rahmawati ${ }^{2}$, Iswadi ${ }^{3}$ : Penerapan Hasil Belajar Matematika Menggunakan Metode Drill dan Resitasi pada Materi Bangun Datar Segitiga 